\title{
ON SOME MULTILINEAR COMMUTATORS IN VARIABLE LEBESGUE SPACES
}

\author{
JiAn TAN, ZONGGUANG LIU AND JiMAN ZHAO
}

Abstract. In this paper, the authors obtain some characterizations of BMO in terms of commutators of multilinear fractional integrals and Caldrón-Zygmund singular integrals on variable Lebesgue spaces. The corresponding weighted estimates for vector-valued commutators and multilinear commutators with vector symbol on variable Lebesgue spaces are also considered.

Mathematics subject classification (2010): 42B25, 42B35.

Keywords and phrases: BMO, multilinear commutators, fractional integrals, singular integrals, variable Lebesgue spaces.

\section{REFERENCES}

[1] C. Capone, D. Cruz-Uribe and A. Fiorenza, The fractional maximal operators and fractional integrals on variable $L^{p}$ spaces, Rev. Mat. Iberoam, 23 (2007), 743-770.

[2] L. CHAFFEE, Commutators of multilinear singular integral operators with pointwise multiplication, Thesis (Ph.D.), University of Kansas, 2015.

[3] S. Chanillo, A note on commutators, Indiana Univ. Math. J., 31 (1982), no. 1, 7-16.

[4] R. Colfman, R. Rochberg AND G. Weiss, Factorization theorems for Hardy spaces in several variables, Ann. of Math., 103 (1976), 611-635.

[5] D. Cruz-Uribe, L. Diening And A. Fiorenza, A new proof of the boundedness of maximal operators on variable Lebesgue spaces, Boll. Unione Mat. Ital., (9). 2 (2009), 151-173.

[6] D. CruZ-Uribe And A. Fiorenza, Variable Lebesgue Spaces: Foundations and Harmonic Analysis, Birkhäuser, Basel, 2013.

[7] D. Cruz-Uribe, A. Fiorenza, J. Martell and C. PÉrez, The boundedness of classical operators on variable $L^{p}$ spaces, Ann. Acad. Sci. Fenn. Math., 31 (2006), 239-264.

[8] D. CruZ-Uribe, J. Martell And C. PÉrez, Extrapolation from $A_{\infty}$ weights and applications, J. Funct. Anal., 213 (2004), 412-439.

[9] D. CRuZ-Uribe AND L. WANG, Extrapolation and weighted norm inqualities in the variable Lebesgue spaces, Trans. Amer. Math. Soc., to appear.

[10] D. CruZ-Uribe And L. WAng, Variable Hardy spaces, Indiana Univ. Math. J., 63 (2014), no. 2, 447-493.

[11] X. CHEN AND Q. XUE, Weighted estimates for a class of multilinear fractional type operators, J. Math. Anal. Appl., 362 (2010), 355-373.

[12] L. Diening, P. Harjulehto, P. Hästö, Y. Mizuta And T. Shimomura, Maximal functions in variable exponent spaces: limiting cases of the exponent, Ann. Acad. Sci. Fenn. Math., 34 (2009), 503-522.

[13] L. Diening, P. HaRJulehto, P. Hëstö And M. RŮZ̆IČKa, Lebesgue and Sobolev spaces with variable exponents, Springer, Heidelberg, 2011.

[14] L. Grafakos, On multilinear fractional integrals, Studia Math., 102 (1992), 49-56.

[15] L. Grafakos And N. Kalton, Some remarks on multilinear maps and interpolation, Math. Ann., 319 (2001), 151-180.

[16] L. GRAFAKOS AND R. TORRES, Maximal operator and weighted norm inequalities for multilinear singular integrals, Indiana Univ. Math. J., 51 (2002), 1261-1276. 
[17] L. Grafakos And R. Torres, Multilinear Caldrón-Zygmund theory, Adv. in Math., 165 (2002), $124-164$.

[18] L. I. Hedberg, On certain convolution inequalities, Proc. Amer. Math. Soc. 36 (1972), 505-510.

[19] M. IzUKi, E. NAKai, Y. Sawano, Function spaces with variable exponentsan introduction, Sci. Math. Jpn. 77 (2014), no. 2, 187-315.

[20] M. IZUKI AND Y. SAWANO, Variable Lebesgue norm estimates for BMO functions, Czechoslovak Math., 62 (2012), 717-727.

[21] M. IZUKI, Y. SAWANO AND Y. Tsutsui, Variable Lebesgue norm estimates for BMO functions II, Analysis Math., 40 (2014), 215-230.

[22] S. JASON, Mean oscillation and commutators of singular integral operators, Ark. Mat., 16 (1978), 263-270.

[23] O. KovÁČIK AND J. RÁKosník, On spaces $L^{p(x)}$ and $W^{k, p(x)}$, Czechoslovak Math. J., 41 (1991), 592-618.

[24] C. Kening, And E. Stein, Multilinear estimates and fractional integration, Math. Res. Lett., 6 (1999), 1-15.

[25] K. LI, K. MoEn, W. Sun, Sharp weighted inequalities for multilinear fractional maximal operators and fractional integrals, Math. Nachr., 288 (2015), no. 5-6, 619-632.

[26] S. Lu, Y. Ding AND D. Yan, Singular integrals and related topics, World Scientific Press, Beijing, 2011.

[27] K. Moen, Weighted inequalities for multilinear fractional integral operators, Collect. Math., 60 (2009), no. 2, 213-238.

[28] K. MoEn, New weighted estimates for bilinear fractional integral operators, Trans. Amer. Math. Soc., 366 (2014), no. 2, 627-646.

[29] E. NAKAI AND Y. SAWAno, Hardy spaces with variable exponents and generalized Campanato spaces, J. Funct. Anal., 262 (2012), 3665-3748.

[30] H. NaKano, Modulared Semi-Ordered Linear Spaces, Maruzen Co. Ltd., Tokyo, 1950.

[31] H. NaKano, Topology of linear topological spaces, Maruzen Co., Ltd., Tokyo, 1951.

[32] W. ORLICZ, Über konjugierte Exponentenfolgen, Stud. Math., 3 (1931) 200-211.

[33] C. PÉREZ AND R. TORRES, Sharp maximal function estimates for multilinear singular integrals, Harmonic analysis at Mount Holyoke, Contemp. Math., 320 (2003), 323-331.

[34] C. PÉREZ, R. TRujILlO-GONZÁLEZ, Sharp weighted estimates for multilinear commutators, J. London Math. Soc., 65 (2002), no. 2, 672-692

[35] S. SHIRAI, Necessary and sufficient conditions for boundedness of commutators of fractional integral operators on classical Morrey spaces, Hokkaido Math. J. 35 (2006), no. 3, 683-696.

[36] Y. SAWANO, S. SUGANO AND H. TANAKA, A bilinear estimate for commutators of fractional integral operators, RIMS Kôkyûroku Bessatsu, B43 (2013), 155-170.

[37] J. TAN AND Z. LiU, Some boundedness of homogeneous fractional integrals on variable exponent function spaces, Acta Math. Sinica (Chin. Ser.), 58 (2015), no. 2, 309-320.

[38] J. TAN AND J. ZHAO, Fractional integrals on variable Hardy-Morrey spaces, Acta. Math. Hungar., 148 (2016), no. 1, 174-190.

[39] J. TAN AND J. ZhaO, Rough fractional integrals and its commutators on variable Morrey spaces, C. R. Math. Acad. Sci. Paris, 353 (2015), no. 12, 1117-1122.

[40] A. UchiYama, On the compactness of operators of Hankel type, Tôhoku. Math. J., 20 (1978), 163171.

[41] G. V. Welland, Weighted norm inequalities for fractional integrals, Proc. Amer. Math. Soc., 51 (1975), 143-148. 